\title{
Impacts of Invasive Species on Forest and Grassland Ecosystem Processes in the United States
}

\author{
Chelcy Ford Miniat, Jennifer M. Fraterrigo, \\ Steven T. Brantley, Mac A. Callaham Jr, Susan Cordell, \\ Jeffrey S. Dukes, Christian P. Giardina, Shibu Jose, \\ and Gary Lovett
}

\subsection{Introduction}

In this chapter, we describe current understanding of and identify research gaps on how invasive species directly, and indirectly, affect ecosystem processes. Specifically, we focus on how invasive species can alter the terrestrial carbon, nitrogen, and hydrologic cycles and how changes to these terrestrial cycles cascade to affect water quantity and quality. While invasive species may alter other ecosystem processes, we focus on these due to their importance to policy, to the

\section{F. Miniat $(\triangle)$}

U.S. Department of Agriculture, Forest Service, Southern Research

Station, Coweeta Hydrologic Lab, Otto, NC, USA

e-mail: chelcy.f.miniat@usda.gov

J. M. Fraterrigo

Department of Natural Resources and Environmental Sciences, and the Program in Ecology, Evolution and Conservation Biology, University of Illinois, Urbana, IL, USA

\section{S. T. Brantley}

Jones Center at Ichauway, Newton, GA, USA

M. A. Callaham Jr.

U.S. Department of Agriculture, Forest Service, Southern Research Station, Center for Forest Disturbance Science, Athens, GA, USA

S. Cordell

U.S. Department of Agriculture, Forest Service, Pacific Southwest Research Station, Institute of Pacific Islands Forestry, Hilo, HI, USA

\section{J. S. Dukes}

Forestry and Natural Resources and Biological Sciences, Purdue University, West Lafayette, IN, USA

C. P. Giardina

U.S. Department of Agriculture, Forest Service, Pacific Southwest Research Station, Hilo, HI, USA

S. Jose

College of Agriculture, Food and Natural Resources,

University of Missouri, Columbia, MO, USA

G. Lovett

Cary Institute of Ecosystem Studies, Millbrook, NY, USA public, and to their likely interaction with climate change effects. For example, carbon sequestration and surface water supply originating from forests and grasslands (Caldwell et al. 2014) are important policy and public concerns, and drought frequency and intensity will likely increase with climate change (Vose et al. 2016a). Our goal is to draw generalizations rather than provide details on invasive species effects on a case-by-case basis. We do, however, provide case studies for illustration and draw linkages with other chapters that provide detailed coverage to disturbance regimes (Chap. 5) and types and mechanisms of ecological impact caused by invasive insects (Chap. 2).

Ecosystem processes are hypothesized to change when invading species: (1) acquire resources differently from native species, including differences in space or time, (2) use acquired resources with efficiencies that differ from native species, (3) alter trophic linkages and resulting food webs, and (4) alter the frequency, duration, extent, and/or intensity of disturbances (Vitousek 1990). Most studies agree that invasive plant species increase ecosystem productivity by enhancing carbon sequestration, storage, and cycling (see review by Liao et al. 2008), although results can vary with the invaded ecosystem type and associated climate (Qiu 2015). Invasive species also increase rates of nitrogen cycling in forests and grasslands, but as with carbon, increased cycling rates are not necessarily sustainable and may lead to longer-term shifts in species composition, disturbance regimes, indirect effects of pathogens, invasive animals, and harm to the environment (Lovett et al. 2010b; Qiu 2015). Changes to the terrestrial carbon and nitrogen cycles directly affect the hydrologic balance, with invasive species generally using more water than natives, resulting in lower soil moisture (Cavaleri and Sack 2010; Pysek et al. 2012). Indirect effects to the hydrologic cycle are especially obvious when invasive species differ phenologically or physiologically from natives (Baer et al. 2006; Brantley et al. 2015; 
Cordell and Sandquist 2008). And as with carbon and nitrogen cycling, changes to water cycling become more complex over time as interactive and cascading impacts are fully realized (see Chap. 2).

\subsection{Impacts on Carbon Cycling in Forests and Grasslands}

The impacts of invasive species on the carbon (C) cycle have societal importance for two main reasons. First, carbon inputs are a measure of the amount of energy that plants make available to other species in the ecosystem (e.g., as fiber and forage). Second, carbon stored in the ecosystem is not in the atmosphere, and thus does not contribute to climate change. If invasive species reduce the stores of carbon in the soil or plants, this will tend to warm the planet through a net release of carbon dioxide $\left(\mathrm{CO}_{2}\right)$ to the atmosphere; invasive species that bolster ecosystem carbon storage will tend to reduce atmospheric $\mathrm{CO}_{2}$. Carbon stocks in the soil typically turn over very slowly (Schmidt et al. 2011), so ecosystems in which most of the carbon is belowground are relatively resistant to declines in carbon stocks following invasion (Liao et al. 2008). Those ecosystems with the largest fraction of carbon stored aboveground are more sensitive, as turnover is faster and shifts in plant species composition or mortality can affect the bulk of the carbon stock. Unless a given invasive species covers vast areas and dramatically changes carbon stores of the invaded areas, its overall impact on the global carbon cycle, or even that of the invaded region, will be quite small (see Chap. 2). In aggregate, if invasive species were to have consistent and strong effects on carbon cycling, a perceptible climate feedback is possible.

Research to date shows that invasive species affect carbon cycling in terrestrial ecosystems through a variety of mechanisms (Peltzer et al. 2010). Carbon enters ecosystems through plant production and senescence and is lost via decomposition of senesced or exuded plant material or via disturbance events such as fire. Rate of carbon input, the quality of those inputs, or where in the ecosystem those inputs are released regulates ecosystem carbon balance and system capacity to retain carbon. Because this balance of inputs and losses drives ecosystem carbon storage, invasive plant species that differ meaningfully from natives with respect to inputs or losses will alter terrestrial carbon balance. Such difference can emerge when invasive species have different rates of primary productivity, produce litter or exudates with different chemistry, or allocate carbon differently than natives. Many studies have documented how invasive plant species affect primary production and litter stocks of forests, grasslands, and other ecosystems (e.g., Bradley et al. 2006; Litton et al. 2008). A meta-analysis by Liao et al. (2008) found that across all invasive plant species and eco- system types, aboveground net primary production and litter carbon mass increased by $83 \%$ and $49 \%$, respectively, in invaded ecosystems as compared with native ecosystems. However, it is not clear what fraction of this carbon is sequestered in the ecosystem. Of the studies examining litter decomposition in plant communities with and without invasive species, most have found an acceleration of decomposition after invasion (but see Jo et al. 2016 and Pysek et al. 2012). As a result, invasive species do not always enhance soil carbon stocks and may cause existing soil carbon stocks to decline (e.g., Tamura and Tharayil 2014).

Differences in productivity, litter chemistry, and carbon allocation between native and invasive species can be linked to differences in plant functional traits (van Kleunen et al. 2010), including those associated with resource acquisition, use efficiency, and retention. For example, invasive species often have greater light and nutrient use efficiencies and relative growth rates than native species (Funk and Vitousek 2007; Heberling and Fridley 2013), even among phylogenetically related species (Matzek 2012). Effects on carbon cycling increase with greater differences in traits between the invasive plant species and the resident species they replace (Dukes 2002; Ehrenfeld 2010) and with greater dominance of the invasive plant (Craig et al. 2015; Kramer et al. 2012). However, knowledge of which traits directly affect ecosystem processes, specifically carbon cycling, and how invasion alters allocation patterns remains limited (Drenovsky et al. 2012).

Plant functional types (e.g., deciduous shrubs, annual grasses) represent clusters of plant functional traits and provide a simplified construct for generalizing effects of invasive species on carbon cycling within the context of the ecosystem (e.g., grasslands or forests). In grasslands, invasive deciduous shrubs generally cause carbon stocks to increase in aboveground biomass, coarse roots, and, following senescence and decomposition, soil organic matter (Qiu 2015; Vila et al. 2011). In forests and shrublands, invasive annual grasses generally cause soil carbon stocks to decrease (Kramer et al. 2012; Strickland et al. 2010; Wheeler et al. 2016); however, environmental conditions can alter these effects. In the Southwestern United States, for example, losses of soil carbon exceeded gains in plant biomass carbon following invasion of woody plants on wet but not dry grasslands. This resulted in a net loss in ecosystem carbon in wetter areas and a net gain in ecosystem carbon in drier areas (Jackson et al. 2002).

Biotic conditions can also alter the effects of invasive species. In a replicated common garden experiment, Ammondt and Litton (2012) found that while the invasive guinea grass (Megathyrsus maximus) had 39-94\% higher maximum photosynthetic rate than three native grass species, when it was planted with native species, its aboveground, belowground, and total biomass and tiller production were all lower than 
when it was planted alone, suggesting competition for resources reduced this invasive species' impact. Indeed, resource competition has been proposed to explain why the same invasive species can have differing effects on native communities in different geographical locations (Fraterrigo et al. 2014). In support of this hypothesis, experimental evidence shows that changing the availability of limiting resources (e.g., light, nutrients) can shift the competitive balance between invasive and native species (Concilio et al. 2016; Pearson et al. 2017; Prevey and Seastedt 2014). This could lead to variation in ecosystem impacts if ecosystem processes scale with the invasive species' abundance (Parker et al. 1999). Thus, although there are some general patterns with respect to the effects of invasive species on carbon cycling, the magnitude of these effects remains uncertain. Additionally, human activities or disturbances that alter the availability of limiting resources can influence the effects of invasive species. In many cases, an increase in the availability of a limiting resource will enhance invasive species performance (Daehler 2003), leading to more severe effects. For example, human activities or disturbances that result in increased light availability to forest understories commonly lead to increases in the frequency (Belote et al. 2008) and productivity (Eschtruth and Battles 2009) of invasive species with less shade tolerance, which could enhance invasion effects on resident communities. However, other outcomes are possible. For instance, use of fossil fuels and fertilizers over the past century has increased the amount of biologically reactive nitrogen in the atmosphere, leading to large increases in nitrogen deposition in terrestrial and aquatic ecosystems (Galloway et al. 1995). Elevated nitrogen deposition can impede organic matter decomposition by suppressing extracellular enzyme activities (Janssens et al. 2010). This may lessen the negative effects of invasive species that mine the soil organic matter for nitrogen. For example, the invasive Japanese stiltgrass (Microstegium vimineum (Trin.) A. Camus) was associated with a decline in forest soil carbon stocks when ambient nitrogen availability was low but an increase in forest soil carbon stocks when ambient nitrogen availability was high (Craig et al. 2015). Additional research is needed to determine whether broadscale processes such as atmospheric nitrogen deposition commonly modify carbon effects of other invasive species.

Invasive species on other trophic levels can also alter carbon cycling. Herbivores (including insects) and plant pathogens can alter carbon input rates by affecting plant growth and, over longer periods of time, causing a shift in selective pressures and recruitment success, and thus plant species composition. When these trophic effects result in only minor or short-term changes to plant species composition, ecosystem effects are likely to be restricted to changes in the annual carbon budgets of the ecosystem. However, more profound effects would be expected if the changes result in plants being replaced by other species that possess different resource acquisition and use strategies. While most introduced herbivores and pathogens likely have little effect on carbon inputs and outputs, herbivorous species that reach high densities and pathogens that cause high rates of plant mortality can lead to dramatic changes in rates of carbon cycling (Lovett et al. 2006; Peltzer et al. 2010). In general, widespread defoliation or tree mortality reduces net primary productivity, and increased litterfall and dead plant material enhances decomposition and soil respiration. Over decadal scales, reduction in soil carbon inputs causes a decline in soil and ecosystem respiration (Hicke et al. 2012; Moore et al. 2013). Longer-term effects on carbon cycling are mediated by changes in tree species composition and the resulting alterations of productivity, litter quality, and soil organic matter production and turnover (Lovett et al. 2006).

Invasive earthworms (in North America belonging primarily to two families, the Lumbricidae and the Megascolecidae) can profoundly influence soil physical, chemical, and biological characteristics (Edwards et al. 2013). In agroecosystems, earthworm activity can increase the total amount of carbon protected in slower cycling pools (e.g., Bossuyt et al. 2005). When invasive earthworms establish in forest soils, they can facilitate a redistribution of carbon through the soil profile, with dramatic reductions in the carbon stored in the litter layer (Bohlen et al. 2004; Eisenhauer et al. 2007; Hale et al. 2008). As European earthworm invasions progress in boreal forests, this may have important positive implications for the amount of carbon lost following fires (Cameron et al. 2015). This redistribution of soil carbon also results in changes in microbial community structure (Dempsey et al. 2011), decreases in native arthropod populations (Snyder et al. 2011), and reduced microbial respiration (C mineralization) (Eisenhauer et al. 2007), ultimately affecting the total ecosystem carbon cycle. It is important to note that the effects of earthworms on the carbon cycle of a particular system will depend upon the species involved, with some species having greater relative impacts than others (Chang et al. 2016).

Invasive species can also affect carbon cycling by altering disturbance regimes. Perhaps the most dramatic examples entail invaders changing or introducing fire regimes (Brooks et al. 2004; D'Antonio and Vitousek 1992). For example, in a wide range of seasonally dry tropical forests, invasion by fire-prone grasses can result in accentuated or in some cases novel fire regimes (D'Antonio and Vitousek 1992; Hoffmann et al. 2004). In the case of forests or shrublands, heat-related impacts to the roots and stems of overstory vegetation can result in dramatic conversions from forest ecosystems that store large amounts of carbon to low storage grasslands (Litton et al. 2006). Cheatgrass (Bromus tectorum L.), an aggressive and widespread invader in the Western United States, provides an important example of how an invader in a 
temperate climate can alter carbon and nutrient process rates and storage (Jones et al. 2015). Bradley et al. (2006) suggested that cheatgrass has turned the Western United States from a carbon sink to a source; the frequent fires in cheatgrass-invaded regions of the Western United States have released $8 \pm 3 \mathrm{Tg} C$ to the atmosphere and over the next decades will put another $50 \pm 20 \mathrm{Tg} \mathrm{C}$ at risk. In deciduous forests of the Eastern United States, where fire regimes are characterized by low-intensity fires, the invasive Japanese stiltgrass increases fire intensity, which enhances its own recruitment and growth in subsequent years (Wagner and Fraterrigo 2015), and can also suppress tree regeneration (Flory et al. 2015), thereby altering future carbon storage potential.

In summary, invasive species frequently accelerate carbon cycling, potentially making more energy available to other species; however, these effects and their consequences for carbon storage depend on the context - the traits of the invader, the resident species in the invaded ecosystem, and the environmental conditions. Where accelerated carbon uptake is paired with accelerated decomposition, the consequences for carbon storage are not clear. On the other hand, invasive species that accelerate disturbance regimes can lead to significant declines in carbon storage. This pattern has been found for invasive grasses in more arid regions of the Western United States where carbon stocks in soil are relatively low and suggests that this may be a general pattern in other arid areas with low belowground carbon stocks.

\subsection{Impacts on Nutrient Cycling in Forests and Grasslands}

Invasive plant, insect, pathogen, and animal species can drastically alter nutrient cycling in forests and grasslands. Changes in soil nutrient stocks and fluxes can have important implications for ecosystem productivity, atmospheric concentrations of greenhouse gasses, and water quality. Consequently, predicting invasion effects on nutrient cycling is an imperative.

Effects of plant invasion on nutrient cycling have been widely documented and vary considerably among invaders, but several consistent patterns have emerged through metaanalysis of this body of work. Specifically, invasion of grasslands and forests generally increases the amount of nitrogen in aboveground plant tissues (Castro-Diez et al. 2014; Liao et al. 2008; Sardans et al. 2016), stimulates microbial activity, and increases the availability of inorganic nitrogen in invaded soils (Castro-Diez et al. 2014; Lee et al. 2017; Liao et al. 2008). Ehrenfeld et al. (2005) suggested that soil nitrogen availability is enhanced by plant invasion and may promote the fitness of invasive plants, thereby creating a positive feedback. Lee et al. (2012) provided experimental evidence of this positive feedback in soils dominated by Japanese stiltgrass; however, the links between such biogeochemical changes and fitness remain poorly understood for most invasive species. More recently, the results of a global metaanalysis linked the magnitude of invasion effects on nitrogen cycling to trait dissimilarities (Lee et al. 2017). Specifically, effects of plant invasion on soil inorganic nitrogen content were more severe when invaded communities had higher litter nitrogen contents and lower litter carbon-to-nitrogen ratios than native communities. Plant invasion also increased nitrogen mineralization rates and decreased soil carbon-tonitrogen ratios to a greater degree when invaded communities had much lower leaf carbon-to-nitrogen ratios than reference communities. These findings reinforce earlier conclusions regarding the importance of context for understanding and predicting the consequences of invasive species.

Although plant invasion can increase litter nitrogen, the rate of litter decomposition does not consistently increase (Castro-Diez et al. 2014; Jo et al. 2016) and may actually decrease (Vila et al. 2011). This pattern is consistent with the finding that many invasive plant species have higher tissue carbon-to-nitrogen ratios than native species in the communities they invade and can shift nitrogen pools from aboveground to belowground plant tissues (Daneshgar and Jose 2009). Compared to native species, invasive plant species retain a higher proportion of nutrients in photosynthetic tissues (Sardans et al. 2016), potentially reducing the rate at which nitrogen and phosphorus are released to other plant species (Laungani and Knops 2009). This hypothesis is supported by evidence that fluxes of inorganic nitrogen from soil to plants and of stabilized nitrogen from soil organic matter (SOM) to plants consistently increase with invasion, whereas invasion effects on the nitrogen flux from plants to soil are less consistent (Castro-Diez et al. 2014).

Invasion of woodlands by grasses in particular has been shown to accelerate nitrogen-cycling rates. If grass invasion increases fire frequency, then nutrient loss may also increase through burning and volatilization of nutrient-containing compounds (Mack and D'Antonio 2003). Grass invasions can also alter soil pH. For example, cogongrass (Imperata cylindrica (L.) P. Beauv) caused a decrease in soil $\mathrm{pH}$ and in the availability of soil potassium $(\mathrm{K})$ in invaded pine flatwoods in the Southern United States (Collins and Jose 2008), whereas Japanese stiltgrass caused an increase in soil $\mathrm{pH}$ in invaded mixed deciduous forests in the Eastern United States (Craig et al. 2015; Ehrenfeld et al. 2001). In general, soil acidification can be expected to occur when invasive species take up and sequester a large proportion of the cations available in a system or promote nitrate leaching. In contrast, soil alkalinization can be expected to occur when invasive species sequester a large proportion of available anions, such as nitrate. 
Invasive species that can symbiotically fix atmospheric nitrogen $\left(\mathrm{N}_{2}\right)$ have distinct effects on nitrogen cycling. Results of meta-analyses repeatedly show that nitrogenfixing invasive species increase ecosystem nitrogen pool sizes and rates of nitrification to a greater extent and more consistently than nonnitrogen-fixing invasive species (Lee et al. 2017; Liao et al. 2008; Vila et al. 2011). There is limited evidence that invasion by nitrogen-fixing species also has a large, positive effect on the emission of nitrous oxide $\left(\mathrm{N}_{2} \mathrm{O}\right)$, a potent greenhouse gas (Qiu 2015). Invasive nitrogen fixers generally reduce tissue carbon-to-nitrogen ratio; however, responses are highly variable (Liao et al. 2008; Vila et al. 2011)

In Hawaii, where invasion dynamics may differ because the native flora evolved on young, nitrogen-poor volcanic substrates, nitrogen-fixing trees and nutrient-acquisitive species such as grasses can quickly outcompete native species by altering nutrient-cycling regimes. Hughes and Denslow (2005) showed that nitrogen mass from litterfall in invaded forests was 55 times higher than in native forests. Allison and Vitousek (2004) found a 50-fold increase in leaf litter decay rates for invasive plants. It is likely that this magnitude of change not only allows for displacement of the slowergrowing native flora but also potentially facilitates further invasion by nonnitrogen-fixing species, resulting in cascading impacts (see Chap. 2).

Long-term studies are needed to understand fully the ecosystem-level effects of shifts in nutrient dynamics induced by invasion. For example, in a seasonally dry submontane tropical forest, grass invasion can lead to a grassfire cycle partly because postfire nitrogen-rich soils favor grasses (D'Antonio and Vitousek 1992). Over time, these feedbacks can weaken, and elevated nitrogen mineralization rates can return to preinvasion levels. Yet, instead of facilitating native species, this shift benefits invasive nitrogen-fixing woody species that are competitively dominant when nitrogen availability is low (Yelenik and D'Antonio 2013).

Invasive insects and pathogens can cause both short- and long-term changes in nutrient cycling (Lovett et al. 2006). Short-term increases in soil nitrogen availability and leaching can result from the pulse of litter and the reduction in plant nitrogen uptake that may follow defoliation or tree mortality (Orwig et al. 2008; Webb et al. 1995). Productivity in forests is generally reduced in the short term by invasive insects and diseases. For instance, defoliation of eastern forests by the invasive gypsy moth (Lymantria dispar L.) has been shown to reduce net ecosystem production (Clark et al. 2010), host tree growth (Fajvan et al. 2008), and seed production (Gottschalk 1990) in the years immediately following the defoliation. Long-term changes in nutrient cycling arise from indirect effects of invasive species, specifically when the replacement species differs from the host species with respect to their patterns of nutrient uptake, growth, and litter quality. For example, in eastern forests, a complex of an invasive scale insect and an invasive fungus, together known as beech bark disease, is causing American beech (Fagus grandifolia) decline which results in subsequent replacement by sugar maple (Acer saccharum). As a consequence, the ecosystem shows increases in litter decomposition, nitrification, and nitrate leaching from soils (Lovett et al. 2010a) and decreases in soil $\mathrm{CO}_{2}$ efflux (Hancock et al. 2008). As New England stands of eastern hemlock (Tsuga canadensis (L.) Carr.) decline after infestations of the invasive hemlock woolly adelgid (Adelges tsugae) (HWA), their species composition often shifts to dominance by black birch (Betula lenta $\mathrm{L}$.) which results in increased aboveground production and rates of nitrogen uptake but no significant effect on soil respiration (Finzi et al. 2014). Complex tree-soil interactions can also mediate potential responses. For example, in contrast to the responses in New England, hemlock stands in the Southern Appalachians experienced increased soil $\mathrm{CO}_{2}$ efflux and no changes to the nitrogen cycle following eastern hemlock mortality (Knoepp et al. 2011; Nuckolls et al. 2009). This was due primarily to the co-occurrence of rosebay rhododendron (Rhododendron maximum (L.)) and its plant-soil-fungal feedbacks (Hoover and Crossley Jr. 1995; Wurzburger and Hendrick 2007; Wurzburger and Hendrick 2009). When rhododendron was absent from declining hemlock stands, soil nitrogen availability increased after hemlock mortality (Block et al. 2013).

Invasive animals substantially affect forest ecosystem nutrient cycles, and responses depend primarily on the animal's foraging and sheltering behaviors. Perhaps the best studied examples in the continental US forests are feral swine (Sus scrofa) - generalist omnivores that disturb soil and eat numerous types of seeds, invertebrates, and herpetofauna (Bratton 1975; Jolley et al. 2010)—and earthworms (see Chap. 5) that can alter soil nutrient-cycling processes and food webs by consuming and redistributing litter and soil, creating soil pores, and altering soil physical structure due to their burrows and casts (Bohlen et al. 2004; MiggeKleian et al. 2006). Invasive earthworms can nearly eliminate the forest floor if they feed on surface litter (Bohlen et al. 2004). In a study of earthworm-invaded forests in New York State, loss of forest floor reduced the soil carbon pool but not the nitrogen pool and consequently decreased the soil carbon-to-nitrogen ratio (see Sect. 3.2) (Bohlen et al. 2004).

In summary, invasive species frequently accelerate rates of soil and ecosystem nutrient cycling. Emerging evidence suggests that the degree of invasion effects will be larger when the traits of invasive species are distinct from those of the native community. In accordance with this hypothesis, nitrogen-fixing invasive species have among the most pronounced effects on nutrient cycling. Invasive species that cause increased fire severity may also enhance the loss of 
ecosystem nutrients, which can contribute to weakened plant-soil feedbacks over time. As a result, impacts of invasive species may change over time. Additional research is needed to fully understand the long-term effects of invasive plants on nutrient cycling and their role in plant-soildisturbance feedbacks. In the case of invasive insects and pathogens, long-term changes in nutrient cycling can be expected when the replacement species differs from the host species with respect to their patterns of nutrient uptake, growth, and litter quality.

\subsection{Effects of Invasive Species on Water Quantity and Quality}

\subsubsection{Direct Effects of Invasive Plants on Water Quantity}

One of the most important ecosystem processes affected by invasive species is evapotranspiration (ET). Changes in ET can affect multiple components of watershed function including water yield, runoff timing (e.g., stormwater mitigation and maintenance of baseflow), groundwater recharge, and dilution capacity. Water yield and stormflow mitigation are particularly important ecosystem services that support municipal, industrial, and agricultural water supplies and protect human systems from flooding. While scarce, studies that have quantified the effects of invasive species on streamflow at catchment scales show that species conversion from native to invasive species causes substantial (>10\%) declines in streamflow (Jain et al. 2015; reviewed by Salemi et al. 2012). Invasion of riparian areas can alter stream channel morphology, leading to altered timing of hydrologic cycles, such as flood frequency and severity (reviewed by Zavaleta 2000), or can alter groundwater dynamics attributed to greater plant water use (Gordon 1998; Saha et al. 2015).

Because direct measurements of changes in hydrology at catchment scales are scarce (Miller et al. 2013), effects often are inferred from comparative measurements of ET or soil moisture at smaller spatial scales. Many studies that examine water use by invasive plant species have found that ET, or water use per unit ground area, is higher for invasive species than for native species. In a meta-analysis, Calaveri and Sack (2010) showed that across 15 invasive/native paired stands, water use per unit ground area was almost $50 \%$ higher in invaded stands, and some invaders have at least a twofold greater sap-flux density compared to the native tree species (Cavaleri et al. 2014). As a consequence, soil moisture in invaded stands is consistently lower than in uninvaded stands (Pysek et al. 2012), and removing the invasive species generally increases soil moisture (Hata et al. 2015; Michaud et al. 2015). While these studies do not conclusively show that stream runoff and timing are altered (Owens and Moore
2007), they do provide evidence that the overall water balance is altered, with possible changes to baseflow and water yield.

Stand-level changes in transpiration large enough to affect runoff can occur from major changes in either stand structure (e.g., leaf area) or physiology, phenology, or morphology of the dominant species (e.g., transpiration rates, water use efficiency, leaf phenology, xylem or rooting characteristics) (Le Maitre et al. 2015). Invaders have been shown to have functional morphological and/or phenological traits that allow them to maintain rapid gas exchange rates and thus high productivity in the invaded range at times when native species cannot. Analyzing over 80 species in North Carolina, Wolkovich and Cleland (2010) found that invasive species leafed out earlier than native species. And in a common garden experiment involving 43 native, noninvasive and 30 invasive eastern US forest understory species, Fridley (2012) demonstrated that invasive species prolonged the window of carbon gain later into the fall as compared to native species. Both studies suggest that the timing of carbon gain, and thus water use, may be altered in invaded systems. Invasive plants may exploit water resources that native plants do not. For example, morphological traits that allow greater water access and storage (e.g., larger root systems, sapwood crosssectional area, xylem-leaf area ratios) also facilitate greater water use by invaders compared to native species (Caplan and Yeakley 2013; Glenn et al. 2012; Nippert et al. 2010). Xylem anatomy can also confer greater water use by invasive species compared to native species in vernal and autumnal windows in deciduous forests. Among 82 native and nonnative understory, deciduous, woody species common to eastern US deciduous forests, invasive species had xylem traits that conferred higher freezing resistance or droughtinduced cavitation resistance in autumn, thus promoting delayed autumn leaf fall and continued carbon gain when native species were dormant (Yin et al. 2016) (see Box 3.1).

Characteristics such as higher leaf area, dimorphic rooting morphology, or longer leaf-on may have little or no effect in energy-limited systems (see Jones et al. 2012) but substantial effects in water-limited systems as increases in ET tend to be manifested in streamflow (Oishi et al. 2010). Thus, ecosystems characterized by periods of chronic or episodic water limitation may be particularly vulnerable to invasions. Invasive plant species in water-limited ecosystems are not necessarily more tolerant of water stress than native species (Pratt and Black 2006); instead, their invasiveness is due in part to a myriad of physiological and life history traits that allow them to avoid water stress (detailed above). For example, invasive species may possess dimorphic root systems (e.g., saltcedar, Tamarix ramosissima Ledeb.) or adaptive drought dormancy, which allow them to avoid drought conditions and maintain high rates of water use (Ammondt et al. 2013; Germino et al. 2016; Nagler et al. 2003). Many inva- 
Box 3.1 Traits of the Invasive Shrub Amur Honeysuckle

The invasive shrub Amur honeysuckle (Lonicera maackii (Rupr.) Maxim) is one of the most widespread invaders of the Ohio River Valley. Xylem anatomical traits allow this species to leaf out earlier, withstand early spring freezes without leaf mortality, and senesce later in autumn than native shrub species. These traits suggest that the extended leaf-on period and freeze tolerance allow greater water use and carbon gain (McEwan et al. 2009). Further, Amur honeysuckle's transpiration rate is roughly proportional to its basal area, which suggests that it has the potential to reduce streamflow by $10 \%$ or more and affect hydroperiod of ephemeral ponds and streams (Boyce et al. 2012).

Leaves and flowers of Amur honeysuckle (upper), and efforts to remove honeysuckle from the understory of a deciduous forest stand, before and after (middle). Note early leaf-out of honeysuckle in lower photos in spring when other deciduous species have yet to leaf out. Photos courtesy of Bugwood.org, taken by L. Mehrhoff and T. Evans. Distribution of number of reported cases by county of Amur honeysuckle as of December 2016 (lower)(EDDMapS 2016).
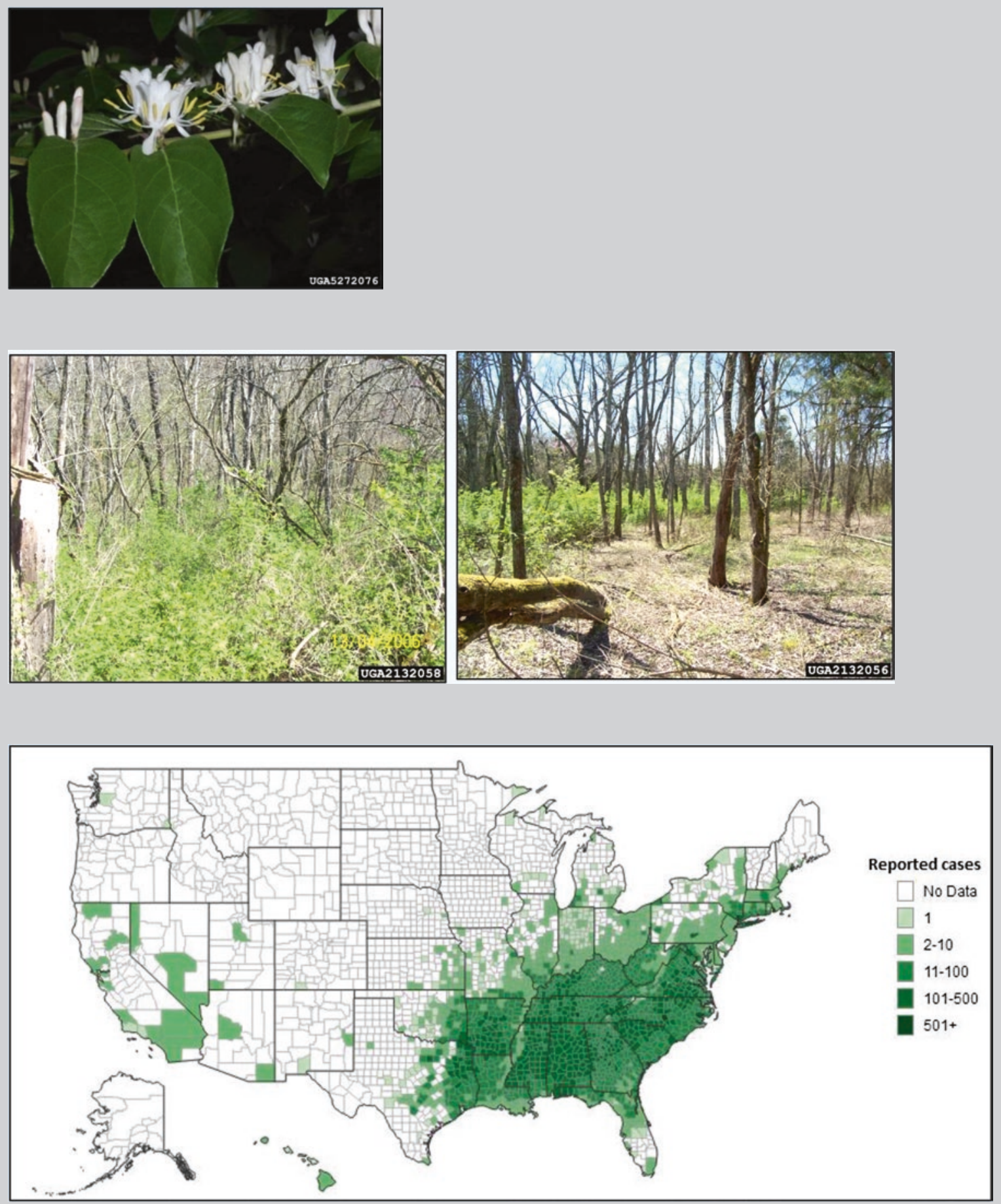
sive species tend to have low leaf construction costs, which facilitate rapid growth and high assimilation and transpiration rates, but these traits may render them more prone to water stress in low-precipitation years if they can't avoid drought (Cordell et al. 2002). Rapid growth and liberal water use may also allow invasive species to take advantage of both carbon fertilization and water savings as climate changes (Peterson et al. 2014). Elevated concentrations of $\mathrm{CO}_{2}$ typically cause a decrease in stomatal conductance, and as a result, stand water use can decline, and soil moisture can increase. One example of this is Dalmatian toadflax (Linaria dalmatica ssp. dalmatica), an invasive forb with C3 metabolism. This invader has an order of magnitude higher biomass and seed production as a result of both enhanced carbon supply and increased soil water compared to the native $\mathrm{C} 3$ and C4 plant community (Blumenthal et al. 2013). Despite the lack of information in the literature, effects of invasion on stream runoff and timing may be highly variable and transient in duration and may interact with other factors such as climate and spatial dynamics (Le Maitre et al. 2015).

\subsubsection{Indirect Effects of Invasive Insects and Pathogens on Water Quantity}

Effects of invasive species aren't limited to the direct effects of invasive plants on ecosystem ET. Invasive insects and pathogens may also affect ecosystem structure and species composition resulting in cascading effects on ecosystem function. Effects from short-term defoliation are moderate or undetectable, but in extreme cases, invasive insects and pathogens may extirpate dominant plant species that have few, if any, defenses against them (Flower et al. 2013; Ford et al. 2012; McManamay et al. 2011; Riscassi and Scanlon 2009). If native species that replace the affected host species have different leaf area, leaf phenology, and/or functional traits than the extirpated species, dramatic alterations in hydrology can occur. For example, when the evergreen eastern hemlock was nearly extirpated from Southern Appalachian riparian forests, the deciduous species that replaced hemlock had lower leaf area, higher leaf-level transpiration rates, and a more pronounced seasonal water use pattern, all affecting watershed hydrology (Brantley et al. 2013; Ford and Vose 2007). While initial annual and winter stand transpiration declined by $22 \%$ and $74 \%$, respectively, following loss of hemlock, positive growth responses of deciduous tree species resulted in $12 \%$ higher stand annual transpiration, $9 \%$ lower annual water yield, and $20 \%$ higher dormant-season peak flows after occurrence of the most extreme storm events (Brantley et al. 2013; Brantley et al. 2015).

\subsubsection{Direct Effects of Invasive Plants on Water Quality}

Invasive plant species can affect water quality through a number of mechanisms including reduced dilution capacity of streams from lower runoff (see Sects. 3.4.1 and 3.4.2), higher suspended sediment loads from increased soil erosion, increased nutrient leaching from altered biogeochemical cycles, and addition of novel plant exudates (Chamier et al. 2012; Ehrenfeld 2003; Nagler et al. 2008). Specific changes to terrestrial biogeochemical cycles that increase nutrient leaching include altered foliar chemistry (e.g., higher foliar $\mathrm{N}$ content), faster $\mathrm{N}$ mineralization rates, and shifts in soil $\mathrm{pH}$ which can cause displacement of cations (see Sect. 3.3). These changes often lead to increased concentrations of water-soluble nutrients, increased rates of nutrient leaching, and ultimately elevated nutrient concentrations in both surface water and groundwater. For example, in the Southwestern United States, invasion of riparian corridors by saltcedar, a halophytic shrub, can elevate soil salinity over time due to existence of salt secretions on the leaf surfaces (Merritt and Shafroth 2012), thus potentially affecting water quality during pulse flooding in this arid region. Increased riparian leaf area after saltcedar invasion also decreases incident light, decreases aquatic macrophyte biomass and chlorophyll in streams, and increases carbon input into streams from leaf litter (Kennedy and Hobbie 2004). Also, in the Southwestern United States, the invasive cheatgrass has displaced native grass species such as black grama (Bouteloua eriopoda). Compared to other native and nonnative grasses, black grama root morphology and resilience to drought stabilize the easily erodible soil; thus, when it disappears, soil erosion increases (Germino et al. 2016) which increases the potential for subsequent loss of water quality.

Invasive plant species that fix atmospheric $\mathrm{N}_{2}$ can cause some of the greatest observed effects on water quality. Symbiotic $\mathrm{N}_{2}$-fixing invasive plants increase rates of $\mathrm{N}$ inputs into ecosystems and increase soil water N (Baer et al. 2006; Goldstein et al. 2010; Vitousek and Walker 1989). Although direct impacts to groundwater and surface water are rare, Jovanovic et al. (2009) showed that groundwater nitrate $\left(\mathrm{NO}_{3}\right)$ concentrations increased after invasion of shrublands with nitrogen-fixing orange wattle (Acacia saligna (Labill.) Wendl. f.). Increasing $\mathrm{N}$ inputs may also exacerbate soil acidification leading to greater leaching of cations into groundwater and surface water (Matson et al. 1999). With increasing frequency and intensity of droughts (Vose et al. $2016 \mathrm{~b}$ ), the impact of $\mathrm{N}_{2}$-fixing invasive plants on water quality may be even greater than anticipated. Drought can decrease soil inorganic N supply (He and Dijkstra 2014; Rennenberg et al. 2009), and in response, $\mathrm{N}_{2}$-fixing plants have been shown to have a competitive advantage over nonfixing species when both water and $\mathrm{N}$ were limiting, due to 
their ability to upregulate $\mathrm{N}_{2}$ fixation (Wurzburger and Miniat 2014).

Other effects of invasive species on water quality and quantity are more complex and/or may only manifest themselves over time. For example, invasions that alter fire regimes may have substantial effects on coupled hydrologic and biogeochemical cycles. Plant invasion often increases standing biomass, changes plant flammability characteristics, alters fuel continuity, and may prolong fire intervals, any or all of which can result in increased wildfire intensity and severity (Chamier et al. 2012; Le Maitre et al. 2014; Smith et al. 2011). A common effect of increasing fire intensity is the generation of water-repellent soil layers, which increase overland flow and soil erosion during storms, resulting in reduced water quality (Smith et al. 2011). For example, areas of grassland that have been invaded by cheatgrass, which increases fuel flammability and the fire return interval by as much as fourfold (Balch et al. 2013; Brooks et al. 2004), have experienced higher rates of soil erosion following fire (Germino et al. 2016), with the potential for reducing water quality.

\subsubsection{Indirect Effects of Invasive Insects and Pathogens on Water Quality}

Invasive insects and pathogens can also have significant impacts on water quality when they induce changes in vegetation structure and composition. Like the indirect effects of invasive insects and pathogens on water quantity, changes tend to be caused by either defoliation or mortality which initiates a cascade of changes in ecosystem structure and function. The most extreme impacts occur when dominant native species are extirpated. Similar to the direct effects of plant invasions, these impacts can be expressed through changes in water chemistry $(\mathrm{N}, \mathrm{P}$, sulfur $(\mathrm{S})$ ), clarity (total suspended solids (TSS)), temperature, and other parameters. For example, in the Eastern United States, small forested watersheds tend to retain the vast majority of $\mathrm{N}(90 \%+)$ under undisturbed or unsaturated conditions (Swank and Vose 1997), e.g., if they receive low $\mathrm{N}$ deposition (Adams et al. 2014; Lovett et al. 2000). One of the most apparent effects of invasive species that cause defoliation is an increase in export of watershed $\mathrm{NO}_{3}$. Large-scale defoliation and/or mortality of dominant tree species caused by invasive species can result in immediate and dramatic increases in $\mathrm{NO}_{3}$ flux to streams (Adams et al. 2014; Lovett et al. 2000; Swank and Vose 1997), with potential negative consequences to water quality downstream. Reasons for increased $\mathrm{N}$ leakage may include less uptake by affected trees, increased litter inputs into streams during defoliation and/or after mortality, increased inputs of insect frass, and a general loosening of the normally conservative $\mathrm{N}$ cycle in these nutrient-limited forests.

The best examples of these effects can be attributed to two invasive insects that occur in the forests of the Central and Southern Appalachian Mountains. In the Central Appalachians, severe gypsy moth defoliation of native hardwoods between 1987 and 1992 resulted in increased groundwater $\mathrm{NO}_{3}$ levels for several years after disturbance (Riscassi and Scanlon 2009). In the Southern Appalachians, HWAcaused mortality of eastern hemlock in the Coweeta Basin that began in 2004 (Ford et al. 2012) resulted in significant increases in $\mathrm{NO}_{3}$ exports in four different forested headwater catchments (Fig. 3.1). Increases in annual $\mathrm{N}$ exports (up to $300 \%$ higher) lasted for 4 years after infestation; however, changes in $\mathrm{NO}_{3}$ exports varied seasonally with greater relative changes in summer. Summer N exports remained significantly higher 7 years after infestation. Other effects of HWA-induced hemlock mortality include increased inputs of litter and wood into streams from dying hemlock and changes in stream temperature due to altered light regimes (Webster et al. 2012). These collective changes may have detrimental impacts on downstream ecosystems that rely on cool, clean water from forested headwaters (Ross et al. 2003). These impacts associated with invasion aren't isolated to the Southern Appalachians. In New England where HWA can decimate entire stands of hemlock, mobile soil $\mathrm{N}$ and stream $\mathrm{NO}_{3}$ are also elevated in areas experiencing higher mortality compared to healthy hemlock stands (Cessna and Nielsen 2012).

Although many forested headwater watersheds are characterized by high water quality, the cumulative effects of invasive species on receiving water bodies could include substantial reduction of water quality with the potential for eutrophication in extreme circumstances. However, more research is needed to directly assess the effects of invasive insects and pathogens on water quality in forests and grasslands.

\subsection{Key Findings}

In general, invasive species effects on carbon and nutrient cycling depend on severity of the invasion, differences in structure (e.g., growth form or leaf area) and function (e.g., phenology) between the invasive species and the species it replaces, and where in the cycle the impact occurs (Table 3.1). For instance, an invasive species could affect the carbon budget by altering productivity, allocation, litter production, decomposition, herbivory, disturbance regimes, or food web structure, and each of these will have different consequences for the ecosystem (Peltzer et al. 2010). We have an emerging understanding of why and under what conditions plant invasions will have the largest effects on 


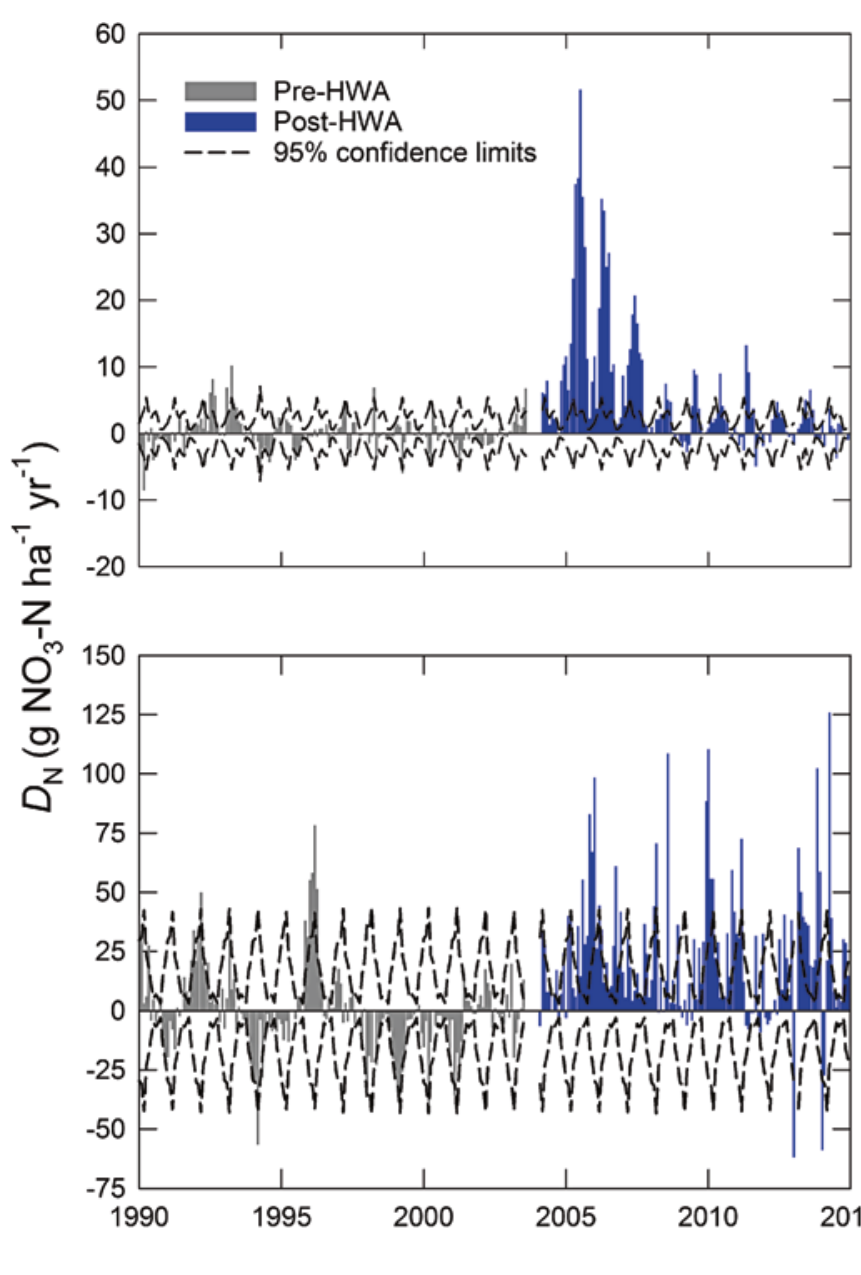

Fig. 3.1 Monthly deviations between observed and expected $\mathrm{NO}_{3} \mathrm{~N}$ flux $\left(D_{\mathrm{N}}\right)$ for four headwater catchments experiencing severe infestation by hemlock woolly adelgid (Adelges tsugae), an invasive insect (see Chap. 2), in the Coweeta Basin. Top two panels are low-elevation (cove hardwood and mixed oak communities) watersheds (WS14 and WS18), while bottom two panels are high-elevation (northern hardwood, cove hardwood, and mixed oak communities) watersheds (WS27 and WS36). Note scale difference between upper and lower panels. Gray bars represent $D_{\mathrm{N}}$ during the calibration period; blue bars represent $D_{\mathrm{N}}$ during

biogeochemical processes (Pysek et al. 2012). Effects often vary substantially across space for the same species, suggesting that environmental conditions play an important but overlooked role in determining invasive species impacts (Block et al. 2012; Block et al. 2013; Craig et al. 2015). Recent studies indicate that many invasive plants possess functional traits associated with high capacity for nutrient acquisition and carbon fixation (Heberling and Fridley 2013; Jo et al. 2015). Because such traits are linked to biogeochemical cycling (Diaz and Cabido 2001), assessment of these attributes will lead to new insights about how invasion may alter biogeochemical processes. In addition, there is growing appreciation that biotic interactions with species of the recipient community may determine invasion effects
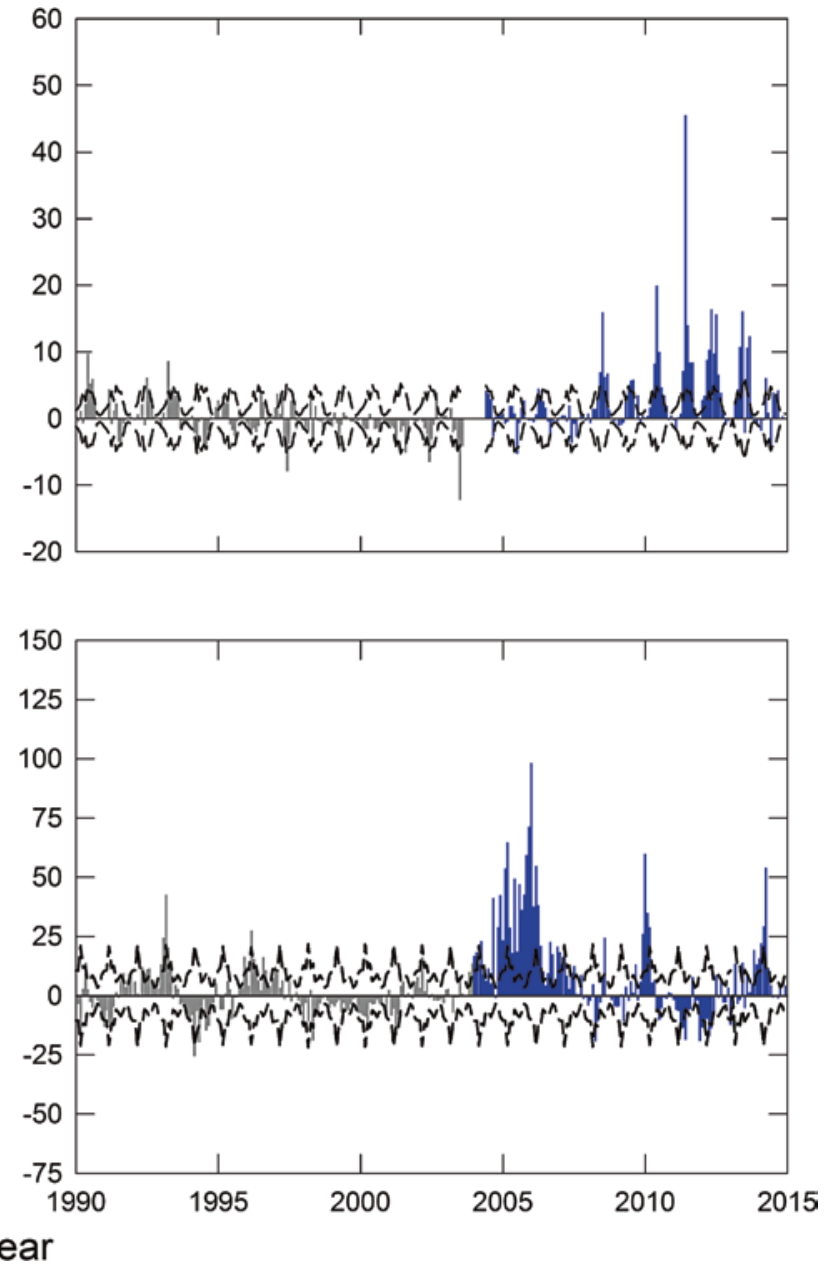

and after infestation. Lines are 95\% confidence intervals, bars lying within which are not statistically significantly different than expected (S. Brantley and C. Miniat, unpublished data). Briefly, we used the paired watershed approach, pairing reference watersheds with relatively high proportions of eastern hemlock basal area in the riparian zones with a reference watershed with relatively low eastern hemlock basal area in the riparian zone (WS2, see Brantley et al. 2015). Site descriptions and water chemistry methods are detailed by Webster et al. (2016)

(Ehrenfeld 2003; Kumschick et al. 2015). For invasive insects and pathogens, the key factors that determine the impact on ecosystem processes are the lethality and host specificity of the insect or pathogen and the dominance and uniqueness of the host tree (Lovett et al. 2006). With regard to ecosystem carbon and nutrient cycling, a key question is whether the invasion produces a long-term shift in the dominant plant species in the ecosystem. If so, enhanced knowledge of the community dynamics and the functional traits of the declining and increasing species will be needed in order to predict the future functioning of the ecosystem. To predict how biogeochemical processes will change after invasions, it's imperative that we develop a mechanistically based framework that merges our understanding of how the 
Table 3.1 Summary of observed changes in community structure, corresponding changes in ecosystem function, and the effects on ecosystem services from invasive species

\begin{tabular}{|c|c|c|c|}
\hline & \multicolumn{2}{|l|}{ Mechanisms } & \multirow[t]{2}{*}{ Commonly observed effects } \\
\hline & Frequently observed changes in structure & $\begin{array}{l}\text { Examples of changes in } \\
\text { function }\end{array}$ & \\
\hline \multirow[t]{4}{*}{$\frac{\text { Carbon }}{\text { cycling }}$} & $\begin{array}{l}\text { Graduated increase/decrease in plant functional } \\
\text { type for the ecosystem context (e.g., increase, } \\
\text { change from grasses in grasslands to shrubs, } \\
\text { change from shrubs in shrublands to trees; } \\
\text { decrease, forests or shrublands invaded by grasses) }\end{array}$ & $\begin{array}{l}\text { Increases/decreases in } \\
\text { aboveground and } \\
\text { belowground biomass and } \\
\text { soil organic matter }\end{array}$ & $\begin{array}{l}\text { Increases/decreases in carbon stocks but } \\
\text { depends on } \mathrm{N} \text { and water availability and } \\
\text { competition }\end{array}$ \\
\hline & Decrease in leaf area from herbivory & $\begin{array}{l}\text { Short-term decrease in } \\
\text { primary productivity and } \\
\text { increased litterfall and } \\
\text { dead plant material }\end{array}$ & Altered disturbance regime (e.g., fire) \\
\hline & $\begin{array}{l}\text { Altered plant species composition (mortality of } \\
\text { dominant species) }\end{array}$ & \multirow{2}{*}{$\begin{array}{l}\text { Decreased litter layer } \\
\text { carbon, increased soil } \\
\text { organic matter }\end{array}$} & Decreased annual carbon budget \\
\hline & Introduction of earthworms & & Protection of carbon in slower cycling pools \\
\hline \multirow[t]{4}{*}{$\frac{\text { Nutrient }}{\text { cycling }}$} & $\begin{array}{l}\text { Increase in biomass of species associated with high } \\
\text { rates of resource acquisition }\end{array}$ & $\begin{array}{l}\text { Short- to long-term } \\
\text { increases in soil nitrogen } \\
\text { availability and nitrogen- } \\
\text { cycling rates }\end{array}$ & $\begin{array}{l}\text { Increased litter nitrogen content, lower tissue } \\
\text { carbon-to-nitrogen ratios, increased fluxes of } \\
\text { inorganic nitrogen from soil to plants, and } \\
\text { stabilized nitrogen from soil organic matter } \\
\text { to plants }\end{array}$ \\
\hline & Grass invasion of woodlands or shrublands & $\begin{array}{l}\text { Loss of nutrients through } \\
\text { burning or volatilization of } \\
\text { nutrient-containing } \\
\text { compounds }\end{array}$ & Increase in fire severity \\
\hline & Introduction of nitrogen-fixing invasive species & \multirow{2}{*}{$\begin{array}{l}\text { Replacement by fast- } \\
\text { growing species with low } \\
\text { tissue construction costs }\end{array}$} & $\begin{array}{l}\text { Increased ecosystem nitrogen pools and rates } \\
\text { of nitrification }\end{array}$ \\
\hline & $\begin{array}{l}\text { Altered species composition (mortality of dominant } \\
\text { species) }\end{array}$ & & $\begin{array}{l}\text { Increased litter decomposition, nitrification, } \\
\text { and nitrate leaching from soils }\end{array}$ \\
\hline \multirow[t]{4}{*}{$\frac{\text { Water }}{\text { quantity }}$} & Altered species composition & $\begin{array}{l}\text { Altered canopy phenology } \\
\text { (e.g., longer leaf-on, lower } \\
\text { winter leaf area) }\end{array}$ & $\begin{array}{l}\text { Decline in water yield (e.g., reduced stream } \\
\text { runoff) }\end{array}$ \\
\hline & $\begin{array}{l}\text { Changes in dominant plant functional group (i.e., } \\
\text { tree, shrub, vine, or grass) }\end{array}$ & \multirow{3}{*}{$\begin{array}{l}\text { 1.1.Increased water use at } \\
\text { tree, stand, and watershed } \\
\text { scales }\end{array}$} & \multirow[t]{3}{*}{$\begin{array}{l}\text { 1.1.Altered stormflow dynamics (e.g., higher } \\
\text { peak flows and/or lower minimum flows) }\end{array}$} \\
\hline & Changes in leaf habit (deciduous vs. evergreen) & & \\
\hline & Increases in sapwood area and leaf area & & \\
\hline \multirow[t]{6}{*}{$\frac{\text { Water }}{\text { quality }}$} & Altered species composition & Shift to $\mathrm{N}_{2}$ fixation & $\begin{array}{l}\text { Increased stream nutrient concentrations } \\
\text { (especially } \mathrm{N} \text { and cations) }\end{array}$ \\
\hline & $\begin{array}{l}\text { Changes in dominant plant functional group (i.e., } \\
\text { tree, shrub, vine, or grass) }\end{array}$ & Altered soil $\mathrm{pH}$ & Increased stream salinity \\
\hline & Increases in sapwood area and leaf area & $\begin{array}{l}\text { Reduced watershed } \\
\text { nutrient retention }\end{array}$ & Higher sedimentation \\
\hline & Altered leaf chemistry & Changes in fire frequency & \multirow{3}{*}{$\begin{array}{l}\text { 1.1.Changes in stream community } \\
\text { composition and/or productivity }\end{array}$} \\
\hline & \multirow[t]{2}{*}{ Changes in root morphology } & $\begin{array}{l}\text { Increased fire severity and } \\
\text { intensity }\end{array}$ & \\
\hline & & Loss of soil stability & \\
\hline
\end{tabular}

functional traits of invaders and other species in the recipient community, and their biotic interactions, create context dependency in invasion effects.

In conclusion, many of our ecosystems have reached a point where healthy functions that effectively store carbon and promote sustainable nutrient and water balance are in a more tenuous balance owing to the effects of invasive species. Sustaining ecosystems that store more carbon than they release and that regulate nutrient and water cycles will become more challenging in the future and will require using a creative blend of old and new land management tools.

\subsection{Key Information Needs}

1. While invasive species increase ecosystem productivity in many cases, it is not clear what possible and potential tradeoffs associated with increased productivity are. Several questions need to be answered. Over time, are the levels of carbon inputs due to invasive species sustainable? What are the direct and indirect impacts of other trophic level invaders on carbon cycling? For example, what are the long-term carbon cycle impacts attributed to invasive species-induced shifts in species composition? How will the indirect effects of invasive pathogens alter 
carbon cycling if tree mortality and defoliation episodes increase?

2. Additional research is needed to determine whether broadscale processes such as atmospheric nitrogen deposition can explain context dependence in carbon effects of other invasive species.

3. In order to predict the impact of invasions on biogeochemical processes, we need to develop a mechanistically based framework that merges our understanding of how the functional traits of invaders and species in the recipient community, and their biotic interactions, create context dependency in invasion effects.

4. Does enhanced soil $\mathrm{N}$ availability induced by plant invasion promote the fitness of invasive plants, thereby creating a positive feedback? The links between such biogeochemical changes and fitness remain poorly understood for most invasive species.

5. Long-term studies, or expanded use of experimental addition and removal studies, are needed to understand fully the ecosystem-level effects of shifts in nutrient dynamics. Specifically, before-and-after invasion measurements on ecosystem processes are needed over the long periods required to characterize the full range of variability of ecosystem processes (Stricker et al. 2015).

6. Increased efforts to document the extent and severity of invasions are recommended to establish broader-scale impacts.

7. Few studies have assessed the direct and indirect effects of invasive species on water quality and quantity. Impacts have been inferred from measurements at smaller spatial scales that may not be appropriate for larger-scale processes (Owens and Moore 2007). More whole-watershed studies are needed to directly assess water quality effects of invasive insects and pathogens in forests and grasslands.

Disclaimer Text The findings and conclusions in this publication are those of the authors and should not be construed to represent any official USDA or U.S. Government determination or policy.

\section{Literature Cited}

Adams MB, Knoepp JD, Webster JR (2014) Inorganic nitrogen retention by watersheds at Fernow Experimental Forest and Coweeta Hydrologic Laboratory. Soil Sci Soc Am J 78:S84-S94

Allison SD, Vitousek PM (2004) Rapid nutrient cycling in leaf litter from invasive plants in Hawai'i. Oecologia 141:612-619

Ammondt SA, Litton CM (2012) Competition between native Hawaiian plants and the invasive grass Megathyrsus maximus: implications of functional diversity for ecological restoration. Restor Ecol 20:638-646

Ammondt SA, Litton CM, Ellsworth LM, Leary JK (2013) Restoration of native plant communities in a Hawaiian dry lowland ecosystem dominated by the invasive grass Megathyrsus maximus. Appl Veg Sci 16:29-39

Baer SG, Church JM, Williard KWJ, Groninger JW (2006) Changes in intrasystem $\mathrm{N}$ cycling from $\mathrm{N}$-2-fixing shrub encroachment in grassland: multiple positive feedbacks. Agric Ecosyst Environ 115:174-182

Balch JK, Bradley BA, D'Antonio CM, Gomez-Dans J (2013) Introduced annual grass increases regional fire activity across the arid western USA (1980-2009). Glob Chang Biol 19:173-183

Belote RT, Jones RH, Hood SM, Wender BW (2008) Diversityinvasibility across an experimental disturbance gradient in Appalachian forests. Ecology 89:183-192

Block CE, Knoepp JD, Elliott KJ, Fraterrigo JM (2012) Impacts of hemlock loss on nitrogen retention vary with soil nitrogen availability in the southern Appalachian Mountains. Ecosystems 15:1108-1120

Block CE, Knoepp JD, Fraterrigo JM (2013) Interactive effects of disturbance and nitrogen availability on phosphorus dynamics of southern Appalachian forests. Biogeochemistry 112:329-342

Blumenthal DM, Resco V, Morgan JA et al (2013) Invasive forb benefits from water savings by native plants and carbon fertilization under elevated $\mathrm{CO}_{2}$ and warming. New Phytol 200:1156-1165

Bohlen PJ, Groffman PM, Fahey TJ et al (2004) Ecosystem consequences of exotic earthworm invasion of north temperate forests. Ecosystems 7:1-12

Bossuyt H, Six J, Hendrix PF (2005) Protection of soil carbon by microaggregates within earthworm casts. Soil Biol Biochem 37:251-258

Boyce RL, Durtsche RD, Fugal SL (2012) Impact of the invasive shrub Lonicera maackii on stand transpiration and ecosystem hydrology in a wetland forest. Biol Invasions 14:671-680

Bradley BA, Houghton RA, Mustard JF, Hamburg SP (2006) Invasive grass reduces aboveground carbon stocks in shrublands of the Western US. Glob Chang Biol 12:1815-1822

Brantley S, Ford CR, Vose JM (2013) Future species composition will affect forest water use after loss of eastern hemlock from southern Appalachian forests. Ecol Appl 23:777-790

Brantley ST, Miniat CF, Elliott KJ et al (2015) Changes to southern Appalachian water yield and stormflow after loss of a foundation species. Ecohydrology 8:518-528

Bratton SP (1975) Effect of European wild boar, Sus scrofa, on gray beech forest in Great Smoky Mountains. Ecology 56:1356-1366

Brooks ML, D'Antonio CM, Richardson DM et al (2004) Effects of invasive alien plants on fire regimes. Bioscience 54:677-688

Caldwell P, Muldoon C, Miniat CF et al (2014) Quantifying the role of National Forest System Lands in providing surface drinking water supply for the Southern U.S. USDA-Forest Service, Southern Research Station, Asheville, $144 \mathrm{p}$

Cameron EK, Shaw CH, Bayne EM et al (2015) Modelling interacting effects of invasive earthworms and wildfire on forest floor carbon storage in the boreal forest. Soil Biol Biochem 88:189-196

Caplan JS, Yeakley JA (2013) Functional morphology underlies performance differences among invasive and non-invasive ruderal Rubus species. Oecologia 173:363-374

Castro-Diez P, Godoy O, Alonso A et al (2014) What explains variation in the impacts of exotic plant invasions on the nitrogen cycle? A meta-analysis. Ecol Lett 17:1-12

Cavaleri MA, Sack L (2010) Comparative water use of native and invasive plants at multiple scales: a global meta-analysis. Ecology 91:2705-2715

Cavaleri MA, Ostertag R, Cordell S, Sack L (2014) Native trees show conservative water use relative to invasive trees: results from a removal experiment in a Hawaiian wet forest. Conser Physiol $2: 1-14$

Cessna JF, Nielsen C (2012) Influences of hemlock woolly adelgidinduced stand-level mortality on nitrogen cycling and stream water nitrogen concentrations in southern Pennsylvania. Castanea 77:127-135

Chamier J, Schachtschneider K, le Maitre DC et al (2012) Impacts of invasive alien plants on water quality, with particular emphasis on South Africa. Water SA 38:345-356

Chang C-H, Szlavecz K, Buyer JS (2016) Species-specific effects of earthworms on microbial communities and the fate of litter-derived carbon. Soil Biol Biochem 100:129-139 
Clark KL, Skowronski N, Hom J (2010) Invasive insects impact forest carbon dynamics. Glob Chang Biol 16:88-101

Collins AR, Jose S (2008) Imperata cylindrica, an exotic invasive grass, changes soil chemical properties of forest ecosystems in the southeastern United States. In: Kohli RK, Jose S, Singh HP, Batish DR (eds) Invasive plants and Forest ecosystems. CRC Press, Boca Raton, $454 \mathrm{p}$

Concilio AL, Nippert JB, Ehrenfeucht S et al (2016) Imposing antecedent global change conditions rapidly alter plant community composition in a mixed-grass prairie. Oecologia 182:899-911

Cordell S, Sandquist DR (2008) The impact of an invasive African bunchgrass (Pennisetum setaceum) on water availability and productivity of canopy trees within a tropical dry forest in Hawai'i. Funct Ecol 22:1008-1017

Cordell S, Cabin R, Hadway L (2002) Physiological ecology of native and alien dry forest shrubs in Hawai'i. Biol Invasions 4:387-396

Craig ME, Pearson SM, Fraterrigo JM (2015) Grass invasion effects on forest soil carbon depend on landscape-level land use patterns. Ecology 96:2265-2279

Daehler CC (2003) Performance comparisons of co-occurring native and alien invasive plants: implications for conservation and restoration. Ann Rev Ecol Evol Syst 34:183-211

Daneshgar P, Jose S (2009) Imperata cylindrica, an alien invasive grass, maintains control over nitrogen availability in an establishing pine forest. Plant Soil 320:209-218

D'Antonio CM, Vitousek PM (1992) Biological invasions by exotic grasses, the grass/fire cycle, and global change. Annu Rev. Ecol Syst 23:63-87

Dempsey MA, Fisk MC, Fahey TJ (2011) Earthworms increase the ratio of bacteria to fungi in northern hardwood forest soils, primarily by eliminating the organic horizon. Soil Biol Biochem 43:2135-2141

Diaz S, Cabido M (2001) Vive la difference: plant functional diversity matters to ecosystem processes. Trends Ecol Evol 16:646-655

Drenovsky RE, Grewell BJ, D'Antonio CM et al (2012) A functional trait perspective on plant invasion. Ann Bot 110:141-153

Dukes JS (2002) Species composition and diversity affect grassland susceptibility and response to invasion. Ecol Appl 12:602-617

EDDMapS (2016) Early detection \& distribution mapping system. The University of Georgia - Center for Invasive Species and Ecosystem Health. Available online at http://www.eddmaps.org/. Last accessed 19 Dec, 2016.

Edwards CA, Hendrix PF, Arancon N (2013) Biology and ecology of Earthworms, 4th edn. Springer US, New York, $422 \mathrm{p}$

Ehrenfeld JG (2003) Effects of exotic plant invasions on soil nutrient cycling processes. Ecosystems 6:503-523

Ehrenfeld JG (2010) Ecosystem consequences of biological invasions. Annu Rev. Ecol Evol Syst 41:59-80

Ehrenfeld JG, Kourtev P, Huang WZ (2001) Changes in soil functions following invasions of exotic understory plants in deciduous forests. Ecol Appl 11:1287-1300

Ehrenfeld JG, Ravit B, Elgersma K (2005) Feedback in the plant-soil system. Annu Rev. Environ Resour 30:75-115

Eisenhauer N, Partsch S, Parkinson D, Scheu S (2007) Invasion of a deciduous forest by earthworms: changes in soil chemistry, microflora, microarthropods and vegetation. Soil Biol Biochem 39:1099-1110

Eschtruth AK, Battles JJ (2009) Assessing the relative importance of disturbance, herbivory, diversity, and propagule pressure in exotic plant invasion. Ecol Monogr 79:265-280

Fajvan MA, Rentch J, Gottschalk K (2008) The effects of thinning and gypsy moth defoliation on wood volume growth in oaks. TreesStructure Funct 22:257-268

Finzi AC, Raymer PCL, Giasson M-A, Orwig DA (2014) Net primary production and soil respiration in New England hemlock forests affected by the hemlock woolly adelgid. Ecosphere 5:1-16

Flory SL, Clay K, Emery SM et al (2015) Fire and non-native grass invasion interact to suppress tree regeneration in temperate deciduous forests. J Appl Ecol 52:992-1000
Flower CE, Knight KS, Gonzalez-Meler MA (2013) Impacts of the emerald ash borer (Agrilus planipennis Fairmaire) induced ash (Fraxinus spp.) mortality on forest carbon cycling and successional dynamics in the eastern United States. Biol Invasions 15:931-944

Ford CR, Vose JM (2007) Tsuga canadensis (L.) Carr. mortality will impact hydrologic processes in southern Appalachian forest ecosystems. Ecol Appl 17:1156-1167

Ford CR, Elliott KJ, Clinton BD et al (2012) Forest dynamics following eastern hemlock mortality in the southern Appalachians. Oikos 121:523-536

Fraterrigo JM, Wagner S, Warren RJ (2014) Local-scale biotic interactions embedded in macroscale climate drivers suggest Eltonian noise hypothesis distribution patterns for an invasive grass. Ecol Lett 17:1447-1454

Fridley JD (2012) Extended leaf phenology and the autumn niche in deciduous forest invasions. Nature 485:359-362

Funk JL, Vitousek PM (2007) Resource-use efficiency and plant invasion in low-resource systems. Nature 446:1079-1081

Galloway JN, Schlesinger WH, Levy H et al (1995) Nitrogen fixation: atmospheric enhancement - environmental response. Glob Biogeochem Cycles 9:235-252

Germino MJ, Belnap J, Stark JM et al (2016) Ecosystem impacts of exotic annual invaders in the genus Bromus. In: Germino $\mathrm{M}$, Chambers J, Brown C (eds) Exotic Brome-Grasses in arid and semiarid ecosystems of the Western US. Springer Cham, Heidelberg, pp 61-95

Glenn EP, Morino K, Nagler PL et al (2012) Roles of saltcedar (Tamarix spp.) and capillary rise in salinizing a non-flooding terrace on a flow-regulated desert river. J Arid Environ 79:56-65

Goldstein CL, Williard KWJ, Schoonover JE et al (2010) Soil and groundwater nitrogen response to invasion by an exotic nitrogenfixing shrub. J Environ Qual 39:1077-1084

Gordon DR (1998) Effects of invasive, non-indigenous plant species on ecosystem processes: lessons from Florida. Ecol Appl 8:975-989

Gottschalk KW (1990) Gypsy moth effects on mast production. In: McGee CE (ed) Proceedings of the workshop: Southern Appalachian mast management; 1989 August 14-16. University of Tennessee, Knoxville, pp 42-50

Hale CM, Frelich LE, Reich PB, Pastor J (2008) Exotic earthworm effects on hardwood forest floor, nutrient availability and native plants: a mesocosm study. Oecologia 155:509-518

Hancock JE, Arthur MA, Weathers KC, Lovett GM (2008) Carbon cycling along a gradient of beech bark disease impact in the Catskill Mountains, New York. Can J For Res 38:1267-1274

Hata K, Kawakami K, Kachi N (2015) Higher soil water availability after removal of a dominant, nonnative tree (Casuarina equisetifolia Forst.) from a subtropical forest. Pac Sci 69:445-460

He MZ, Dijkstra FA (2014) Drought effect on plant nitrogen and phosphorus: a metaanalysis. New Phytol 204:924-931

Heberling JM, Fridley JD (2013) Resource-use strategies of native and invasive plants in Eastern North American forests. New Phytol 200:523-533

Hicke JA, Allen CD, Desai AR et al (2012) Effects of biotic disturbances on forest carbon cycling in the United States and Canada. Glob Chang Biol 18:7-34

Hoffmann WA, Lucatelli VMPC, Silva FJ et al (2004) Impact of the invasive alien grass Melinis minutiflora at the savanna-forest ecotone in the Brazilian Cerrado. Divers Distrib 10:99-103

Hoover CM, Crossley DA Jr (1995) Leaf litter decomposition and microarthropod abundance along an altitudinal gradient. In: Collins HP, Robertson GP, Klug MJ (eds) The significance and regulation of soil biodiversity, Developments in Plant and Soil Sciences, vol 63. Springer, Dordrecht, pp 287-292

Hughes RF, Denslow JS (2005) Invasion by a $\mathrm{N}_{2}$-fixing tree alters function and structure in wet lowland forests of Hawai'i. Ecol Appl $15: 1615-1628$

Jackson RB, Banner JL, Jobbagy EG et al (2002) Ecosystem carbon loss with woody plant invasion of grasslands. Nature 418:623-626 
Jain S, Ale S, Munster CL et al (2015) Simulating the hydrologic impact of Arundo donax invasion on the headwaters of the Nueces River in Texas. Hydrology 2:134-147

Janssens IA, Dieleman W, Luyssaert S et al (2010) Reduction of forest soil respiration in response to nitrogen deposition. Nat Geosci 3:315-322

Jo I, Fridley JD, Frank DA (2015) Linking above- and belowground resource use strategies for native and invasive species of temperate deciduous forests. Biol Invasions 17:1545-1554

Jo I, Fridley JD, Frank DA (2016) More of the same? In situ leaf and root decomposition rates do not vary between 80 native and nonnative deciduous forest species. New Phytol 209:115-122

Jolley DB, Ditchkoff SS, Sparklin BD et al (2010) Estimate of herpetofauna depredation by a population of wild pigs. J Mammal 91:519-524

Jones JA, Creed IF, Hatcher KL et al (2012) Ecosystem processes and human influences regulate streamflow response to climate change at long-term ecological research sites. Bioscience 62:390-404

Jones R, Chambers JC, Johnson DW et al (2015) Effect of repeated burning on plant and soil carbon and nitrogen in cheatgrass (Bromus tectorum) dominated ecosystems. Plant Soil 386:47-64

Jovanovic NZ, Israel S, Tredoux G et al (2009) Nitrogen dynamics in land cleared of alien vegetation (Acacia saligna) and impacts on groundwater at Riverlands Nature Reserve (Western Cape, South Africa). Water SA 35:37-44

Kennedy TA, Hobbie SE (2004) Saltcedar (Tamarix ramosissima) invasion alters organic matter dynamics in a desert stream. Freshw Biol 49:65-76

Knoepp JD, Vose JM, Clinton BD, Hunter MD (2011) Hemlock infestation and mortality: impacts on nutrient pools and cycling in Appalachian forests. Soil Sci Soc Am J 75:1935-1945

Kramer TD, Warren RJ II, Tang Y, Bradford MA (2012) Grass invasions across a regional gradient are associated with declines in belowground carbon pools. Ecosystems 15:1271-1282

Kumschick S, Gaertner M, Vila M et al (2015) Ecological impacts of alien species: quantification, scope, caveats, and recommendations. Bioscience 65:55-63

Laungani R, Knops JMH (2009) Species-driven changes in nitrogen cycling can provide a mechanism for plant invasions. Proc Natl Acad Sci U S A 106:12400-12405

Le Maitre DC, Kotzee IM, O'Farrell PJ (2014) Impacts of land-cover change on the water flow regulation ecosystem service: invasive alien plants, fire and their policy implications. Land Use Policy $36: 171-181$

Le Maitre DC, Gush MB, Dzikiti S (2015) Impacts of invading alien plant species on water flows at stand and catchment scales. AoB Plants 7

Lee MR, Flory SL, Phillips RP (2012) Positive feedbacks to growth of an invasive grass through alteration of nitrogen cycling. Oecologia 170:457-465. https://doi.org/10.1007/s00442-012-2309-9

Lee MR, Bernhardt ES, van Bodegom PM et al (2017) Invasive species' leaf traits and dissimilarity from natives shape their impact on nitrogen cycling: a meta-analysis. New Phytol 213:128-139

Liao CZ, Peng RH, Luo YQ et al (2008) Altered ecosystem carbon and nitrogen cycles by plant invasion: a meta-analysis. New Phytol 177:706-714

Litton CM, Sandquist DR, Cordell S (2006) Effects of non-native grass invasion on aboveground carbon pools and tree population structure in a tropical dry forest of Hawai'i. For Ecol Manag 231:105-113

Litton CM, Sandquist DR, Cordell S (2008) A non-native invasive grass increases soil carbon flux in a Hawai'ian tropical dry forest. Glob Chang Biol 14:726-739

Lovett GM, Weathers KC, Sobczak WV (2000) Nitrogen saturation and retention in forested watersheds of the Catskill Mountains, New York. Ecol Appl 10:73-84

Lovett GM, Canham CD, Arthur MA et al (2006) Forest ecosystem responses to exotic pests and pathogens in eastern North America. Bioscience 56:395-405
Lovett GM, Arthur M, Weathers K, Griffin J (2010a) Long-term changes in forest carbon and nitrogen cycling caused by an introduced pest/ pathogen complex. Ecosystems 13:1188-1200

Lovett GM, Arthur MA, Weathers KC, Griffin JM (2010b) Long-term changes in forest carbon and nitrogen cycling caused by an introduced pest/pathogen complex. Ecosystems 13:1188-1200

Mack MC, D'Antonio CM (2003) Exotic grasses alter controls over soil nitrogen dynamics in a Hawai' ian woodland. Ecol Appl 13:154-166

Matson PA, McDowell WH, Townsend AR, Vitousek PM (1999) The globalization of $\mathrm{N}$ deposition: ecosystem consequences in tropical environments. Biogeochemistry 46:67-83

Matzek V (2012) Trait values, not trait plasticity, best explain invasive species' performance in a changing environment. PLoS One 7:e48821

McEwan RW, Birchfield MK, Schoergendorfer A, Arthur MA (2009) Leaf phenology and freeze tolerance of the invasive shrub Amur honeysuckle and potential native competitors. J Torrey Botanical Soc 136:212-220

McManamay RH, Resler LM, Campbell JB, McManamay RA (2011) Assessing the impacts of balsam woolly adelgid (Adelges piceae Ratz.) and anthropogenic disturbance on the stand structure and mortality of fraser fir [Abies fraseri (Pursh) Poir.] in the Black Mountains, North Carolina. Castanea 76:1-19

Merritt DM, Shafroth PB (2012) Edaphic, salinity, and stand structural trends in chronosequences of native and non-native dominated riparian forests along the Colorado River, USA. Biological Invasions 14:2665-2685

Michaud J, Cordell S, Cole TC, Ostertag R (2015) Drought in an invaded Hawai' ian lowland wet forest. Pac Sci 69:367-383

Migge-Kleian S, McLean MA, Maerz JC, Heneghan L (2006) The influence of invasive earthworms on indigenous fauna in ecosystems previously uninhabited by earthworms. Biol Invasions 8:1275-1285

Miller JH, Lemke D, Coulston J (2013) The invasion of southern forests by nonnative plants: current and future occupation, with impacts, management strategies, and mitigation approaches. In: Wear DN, Greis JG (eds) Southern Forest Futures Project: technical report, Gen. Tech. Rep. SRS-GTR-178. USDA-Forest Service, Southern Research Station, Asheville, pp 397-456

Moore DJP, Trahan NA, Wilkes P et al (2013) Persistent reduced ecosystem respiration after insect disturbance in high elevation forests. Ecol Lett 16:731-737

Nagler PL, Glenn EP, Thompson TL (2003) Comparison of transpiration rates among saltcedar, cottonwood and willow trees by sap flow and canopy temperature methods. Agric For Meteorol 116:73-89

Nagler PL, Glenn EP, Didan K et al (2008) Wide-area estimates of stand structure and water use of Tamarix spp. on the Lower Colorado River: implications for restoration and water management projects. Restor Ecol 16:136-145

Nippert JB, Butler JJ, Kluitenberg GJ et al (2010) Patterns of Tamarix water use during a record drought. Oecologia 162:283-292

Nuckolls AE, Wurzburger N, Ford CR et al (2009) Hemlock declines rapidly with hemlock woolly adelgid infestation: impacts on the carbon cycle of southern Appalachian forests. Ecosystems 12:179-190

Oishi AC, Oren R, Novick KA et al (2010) Interannual invariability of forest evapotranspiration and its consequence to water flow downstream. Ecosystems 13:421-436

Orwig DA, Cobb RC, D'Amato AW et al (2008) Multi-year ecosystem response to hemlock woolly adelgid infestation in southern New England forests. Can J For Res 38:834-843

Owens MK, Moore GW (2007) Saltcedar water use: realistic and unrealistic expectations. Rangel Ecol Manag 60:553-557

Parker IM, Simberloff D, Lonsdale WM et al (1999) Impact: toward a framework for understanding the ecological effects of invaders. Biol Invasions 1:3-19

Pearson DE, Ortega YK, Maron JL (2017) The tortoise and the hare: reducing resource availability shifts competitive balance between plant species. J Ecol 105:999-1009 
Peltzer DA, Allen RB, Lovett GM et al (2010) Effects of biological invasions on forest carbon sequestration. Glob Chang Biol 16:732-746

Peterson DL, Vose JM, Patel-Weynand T (2014) Climate change and United States Forests. Springer, Heidelberg, $261 \mathrm{p}$

Pratt RB, Black RA (2006) Do invasive trees have a hydraulic advantage over native trees? Biol Invasions 8:1331-1341

Prevey JS, Seastedt TR (2014) Seasonality of precipitation interacts with exotic species to alter composition and phenology of a semiarid grassland. J Ecol 102:1549-1561

Pysek P, Jarosik V, Hulme PE et al (2012) A global assessment of invasive plant impacts on resident species, communities and ecosystems: the interaction of impact measures, invading species' traits and environment. Glob Chang Biol 18:1725-1737

Qiu JX (2015) A global synthesis of the effects of biological invasions on greenhouse gas emissions. Glob Ecol Biogeogr 24:1351-1362

Rennenberg H, Dannenmann M, Gessler A et al (2009) Nitrogen balance in forest soils: nutritional limitation of plants under climate change stresses. Plant Biol 11:4-23

Riscassi AL, Scanlon TM (2009) Nitrate variability in hydrological flow paths for three mid-Appalachian forested watersheds following a large-scale defoliation. J Geophys Res Biogeosci 114:G2

Ross RM, Bennett RM, Snyder CD et al (2003) Influence of eastern hemlock (Tsuga canadensis L.) on fish community structure and function in headwater streams of the Delaware River basin. Ecol Freshw Fish 12:60-65

Saha S, Sadle J, van der Heiden C, Sternberg L (2015) Salinity, groundwater, and water uptake depth of plants in coastal uplands of Everglades National Park (Florida, USA). Ecohydrology $8: 128-136$

Salemi LF, Groppo JD, Trevisan R et al (2012) Riparian vegetation and water yield: a synthesis. J Hydrol 454-455:195-202

Sardans J, Bartrons M, Margalef O et al (2016) Plant invasion is associated with higher plant-soil nutrient concentrations in nutrient poorenvironments. Glob Chang Biol 23:1282-1291

Schmidt MW, Torn MS, Abiven S et al (2011) Persistence of soil organic matter as an ecosystem property. Nature 478:49-56

Smith HG, Sheridan GJ, Lane PNJ et al (2011) Wildfire effects on water quality in forest catchments: a review with implications for water supply. J Hydrol 396:170-192

Snyder BA, Callaham MA, Hendrix PF (2011) Spatial variability of an invasive earthworm (Amynthas agrestis) population and potential impacts on soil characteristics and millipedes in the Great Smoky Mountains National Park, USA. Biol Invasions 13:349-358

Stricker KB, Hagan D, Flory SL (2015) Improving methods to evaluate the impacts of plant invasions: lessons from 40 years of research. AoB Plants. plv028.

Strickland MS, Devore JL, Maerz JC, Bradford MA (2010) Grass invasion of a hardwood forest is associated with declines in belowground carbon pools. Glob Chang Biol 16:1338-1350

Swank WT, Vose JM (1997) Long-term nitrogen dynamics of Coweeta forested watersheds in the southeastern United States of America. Glob Biogeochem Cycles 11:657-671

Tamura M, Tharayil N (2014) Plant litter chemistry and microbial priming regulate the accrual, composition and stability of soil carbon in invaded ecosystems. New Phytol 203:110-124 van Kleunen M, Weber E, Fischer M (2010) A meta-analysis of trait differences between invasive and non-invasive plant species. Ecol Lett 13:235-245

Vila M, Espinar JL, Hejda M et al (2011) Ecological impacts of invasive alien plants: a meta-analysis of their effects on species, communities and ecosystems. Ecol Lett 14:702-708

Vitousek PM (1990) Biological invasions and ecosystem processes: towards an integration of population biology and ecosystem studies. Oikos 57:7-13

Vitousek PM, Walker LR (1989) Biological invasion by Myrica faya in Hawai'i: plant demography, nitrogen-fixation, ecosystem effects. Ecol Monogr 59:247-265

Vose JM, Clark JS, Luce C, Patel-Weynand T (eds) (2016a) Effects of drought on forests and rangelands in the United States: a comprehensive science synthesis, General Technical Report WO-93b. USDA Forest Service, Washington Office, Washington, DC, 289 p

Vose JM, Miniat CF, Luce CH et al (2016b) Ecohydrological implications of drought. In: Vose JM, Clark JS, Luce C, Patel-Weynand $\mathrm{T}$ (eds) Effects of drought on forests and rangelands in the United States: a comprehensive science synthesis, General Technical Report WO-93b. USDA Forest Service, Washington Office, Washington, DC, pp 231-251

Wagner SA, Fraterrigo JM (2015) Positive feedbacks between fire and non-native grass invasion in temperate deciduous forests. For Ecol Manag 354:170-176

Webb JR, Cosby BJ, Deviney FA et al (1995) Change in the acid-base status of an Appalachian mountain catchment following forest defoliation by the gypsy moth. Water Air Soil Pollut 85:535-540

Webster JR, Morkeski K, Wojculewski CA et al (2012) Effects of hemlock mortality on streams in the southern Appalachian Mountains. Am Midl Nat 168:112-131

Webster J, Knoepp J, Swank W, Miniat C (2016) Evidence for a regime shift in nitrogen export from a forested watershed. Ecosystems 19:881-895

Wheeler MM, Dipman MM, Adams TA et al (2016) Carbon and nitrogen storage in California sage scrub and non-native grassland habitats. J Arid Environ 129:119-125

Wolkovich EM, Cleland EE (2010) The phenology of plant invasions: a community ecology perspective. Front Ecol Environ 9:287-294

Wurzburger N, Hendrick RL (2007) Rhododendron thickets alter $\mathrm{N}$ cycling and soil extracellular enzyme activities in southern Appalachian hardwood forests. Pedobiologia 50:563-576

Wurzburger N, Hendrick RL (2009) Plant litter chemistry and mycorrhizal roots promote a nitrogen feedback in a temperate forest. $\mathrm{J}$ Ecol 97:528-536

Wurzburger N, Miniat CF (2014) Drought enhances symbiotic dinitrogen fixation and competitive ability of a temperate forest tree. Oecologia 174:1117-1126

Yelenik SG, D'Antonio CM (2013) Self-reinforcing impacts of plant invasions change over time. Nature 503:517-520

Yin J, Fridley JD, Smith MS, Bauerle TL (2016) Xylem vessel traits predict the leaf phenology of native and non-native understorey species of temperate deciduous forests. Funct Ecol 30:206-214

Zavaleta E (2000) The economic value of controlling an invasive shrub. AMBIO J Hum Environ 29:462-467

Open Access This chapter is licensed under the terms of the Creative Commons Attribution 4.0 International License (http://creativecommons. org/licenses/by/4.0/), which permits use, sharing, adaptation, distribution and reproduction in any medium or format, as long as you give appropriate credit to the original author(s) and the source, provide a link to the Creative Commons license and indicate if changes were made.

The images or other third party material in this chapter are included in the chapter's Creative Commons license, unless indicated otherwise in a credit line to the material. If material is not included in the chapter's Creative Commons license and your intended use is not permitted by statutory regulation or exceeds the permitted use, you will need to obtain permission directly from the copyright holder. 